\title{
Membangun Kembali Aceh: Reinvigorasi Syariat Islam Pasca Mahkamah Syariah
}

\author{
Agus Triyanta
}

\section{Abstrak}

Reconstruction of Aceh Darussalam as a potential momentum to strengthen the application of Islamic Syariah is significant, because Islamic Syariah as a legal system relates to law enforcement. It includes three aspects such as state apparatus, substantial law, and development of legal culture.

\section{Pengantar}

Blueprint (cetak biru) dari pembangunan kembali Nanggroe Aceh Darussalam (NAD) pasca bencana sudah ditandatangani Presiden 15 April 2005 yang lalu. ${ }^{1}$ Blueprint itu, dalam tingkat tertentu dapat menjadi bagian dari upaya rekonsiliasi politik antara pemerintah pusat dengan masyarakat di NAD. Hal itu disebabkan, karena kondisi tersebut merupakan momentum yang strategis bagi upaya 'balas budi' pemerintah terhadap warga NAD. Memang, kehancuran sarana-prasarana fisik, diikuti dengan luka psikologis yang mendalam (sebagian bahkan akut), telah membuktikan betapa beberapa kota penting di NAD kehidupan harus mulai dari nol. Atas dasar itulah maka kemudian pembangunan kembali di wilayah ini memerlukan sebuah blueprint yang benar-benar matang. Tanpa adanya blueprint yang baik, terarah dan terpadu, tidak mustahil, masa depan NAD adalah kelahiran sebuah kesemrawutan baru, baik dari aspek birokratis maupun sosial dengan segala bagiannya.

Pengalaman dalam 'membangun Indonesia Baru' yang tidak melalui blueprint yang jelas telah melahirkan chaos politik di tengah euforia dan menjadikan masa depan Indonesia seakan sangat mengambang, lebih ditentukan oleh berbagai kelompok dominan yang mampu menguasai situasi, baik di level eksekutif, legislatif maupun sosial. Suasana 'hidup tanpa kepastian' kian memanjang dan . sulit diterka kapan akan berakhir. Trial and error berbagai produk perundang-undangan dan kebijakan politik semakin meneguhkan tesis tersebut. Penegakan hukum pun, sulit menemukan suasana kondusifnya. Sebagai hiburannya, orang akan menyatakan bahwa ini adalah "tahapan normal dalam perjalanan peradaban suatu bangsa', seraya melupakan bahwa banyak bangsa lain yang dapat

'Republika, 16 April 2005 
mencapai kemajuan tanpa harus 'babak belur' terlebih dahulu. Mana yang lebih baik antara keduanya, jawabannya sangat bisa beragam.

Di sinilah blueprint bagi pembangunan kembali NAD menjadi relevan dan signifikan. Dan tentu saja, implementasi dari blueprint tersebut haruslah betul-betul mempertimbangkan berbagai aspek, terutama dari masyarakat kekhasan NAD. Dengan kata lain, dalam tingkat tertentu blueprint tersebut harus mampu mengakomodasikan kepentingan masyarakat Aceh. Minimal, dikarenakan blueprint itu sendiri sudah jadi, maka, dalam berbagai implementasinya haruslah mempertimbangkan kepentingan lokal. Harus dihindari berbagai kepentingan praktis yang hanya bertujuan untuk kepentingan sesaat, apalagi hanya kepentingan ekonomi dari pihak-pihak tertentu yang terlibat dalam proyek-proyek pembangunan kembali NAD. Mengingat, bahwa dengan terjadinya bencana tsunami, telah mampu membangkitkan solidaritas yang berupa mengalirkan banyak bantuan, bukan hanya pada lingkup nasional, namun, dunia internasional pun telah mengucurkan bantuan yang tidak sedikit jumlahnya. Karena itulah, diharapkan tidak ada kepentingan yang 'mendikte' dalam pembangunan kembali Aceh tersebut.

Pembangunan kembali Aceh tentunya bukan hanya bersifat fisik saja, namun masalah yang lebih penting untuk dicermati adalah, pembangunan kembali sumber daya manusia (SDM). Kehancuran SDM di Aceh, yang ditunjukkan dengan statistik yang menyatakan korban meninggal lebih dari 100.000 , telah menyisakan kekosongan SDM yang cukup besar. Kondisi semacam ini, sedikit banyak tentu akan berpengaruh pada sistem pemerintahan dan penegakan hukum. Atas dasar itulah, artikel ini bermaksud untuk mendiskusikan pembangunan kembali NAD dalam kaitannya dengan pemberlakuan syariat Islam.

\section{Aceh dan Otonomi Khusus}

Aceh memang terbukti memiliki keistimewaan. Baik dari segi latar belakang, sosiologis maupun politis. Otonomi Khusus yang lahir pada tahun 2001 sebenarnya merupakan ujung dari upaya 'negosiasi' antara pemerintah $\mathrm{Rl}$ dengan masyarakat Aceh. Diharapkan dengan adanya otonomi khusus tersebut berbagai persoalan di tanah rencong akan -minimal secara politis-teratasi. Sehingga, jika dilihat dari luasnya kewenangan yang diberikan kepada pemerintah Daerah di NAD, hal itu bukanlah sesuatu yang layak diirikan oleh berbagai daerah lain di wilayah RI. Hal ini, tentu saja semakin mengukuhkan ciri khas NAD sebagai sebuah daerah khusus, yang sebenarnya sudah disadari sejak lama namun sengaja ditutupi tabir sentralisasi kekuasaan (baca:ekønomi).

Melihat UU Nomor 18 Tahun 2001 Tentang Otonomil Khusus Bagi Provinsi Daerah Istimewa Acehi Sebagai Provinsi Nanggroe Aceh Darussalam, terlihat bahwa wilayah ini memilikii otonomi yang, berbeda dengan wilayah lain' manapun dii Indonesia! Adapun yang merupakan hal-hal pokok dari otonomi khusus di NAD itu, antara lain adalah sebagai berikut:

Pertama, NAD memiliki institusi pemersatu adat, yang sudah jelas berlandaskan nilai-nilai syariat Islam. Yang dimaksud dengan hal ini adalah adanya Wali Nanggroe atau istilah lainnya adalah Tuha Nanggroe. Hal ini disebutkan 
dalam bab VII Pasal 10 :

1) Wali Nanggroe dan Tuha Nanggroe adalah lembaga yang merupakan simbol bagi pelestarian penyelenggaraan kehidupan adat, budaya, dan pemersatu masyarakat di Provinsi Nanggroe Aceh Darussalam.

2) Wali Nanggroe dan Tuha Nanggroe bukan merupakan lembaga politik dan pemerintahan dalam Provinsi Nanggroe Aceh Darussalam.

3) Hal-hal sebagaimana dimaksud pada ayat (1) dan ayat (2) diatur lebih lanjut dengan Qanun Provinsi Nanggroe Aceh Darussalam.

Kedua, dalam bab XII Pasal 25 disebutkan permasalahan yang berkaitan dengan pemberlakuan syariat Islam yang lebih dari wilayah lain, yakni dengan diberikannya lembaga peradilan -sebagai sarana penegakan hukum tersebut-yang disebut dengan Mahkamah Syaniah. Selengkapnya pasal tersebut berbunyi: 1) Mahkamah Syar'iyah sebagaimana dimaksud dalam Pasal 25 ayat (1) terdiri atas Mahkamah Syar'iyah Kabupaten/ Sagoee dan Kota/Banda atau nama lain sebagai pengadilan tingkat pertama, dan Mahkamah Syar'iyah Provinsi sebagai pengadilan tingkat banding di ibukota Provinsi Nanggroe Aceh Darussalam.

2) Mahkamah Syar'iyah untuk pengadilan tingkat kasasi dilakukan pada Mahkamah Agung Republik Indonesia.

3) Hakim Mahkamah Syariyah diangkat dan diberhentikan oleh Presiden sebagai Kepala Negara atas usul Menteri Kehakiman setelah mendapat pertimbangan Gubernur Provinsi Nanggroe Aceh Darussalam dan Ketua Mahkamah Agung.
Ketiga, dalam hal keuangan, sumber pendapatan asli daerah berasal antara lain dari zakat. Hal ini berarti, dengan pencantuman tersebut dimungkinkan bahwa peraturan zakat bisa dimplementasikan secara formal. Hal ini tercantum dalam Pasal 4 yang berbunyi:

1) Sumber penerimaan Provinsi Nanggroe Aceh Darussalam meliputi:

a. pendapatan asli Daerah Provinsi Nanggroe Aceh Darussalam;

b. dana perimbangan;

c. penerimaan Provinsi Nanggroe Aceh Darussalam dalam rangka otonomi khusus;

d. pinjaman Daerah; dan

e. lain-lain penerimaan yang sah.

2) Sumber pendapatan asli Daerah Provinsi Nanggroe Aceh Darussalam, sebagaimana dimaksud pada ayat (1) hunuf a, terdin atas:

a. pajak Daerah;

b. retribusi Daerah;

c. zakat;

d. hasil perusahaan milik Daerah dan hasil pengelolaan kekayaan daerah lainnya yang dipisahkan; dan

e. lain-lain pendapatan Daerah yang sah.

Minimal, dengan tiga perbedaan yang menunjukkan kekhasan tersebut telah memberikan otonomi bagi NAD dengan perbedaan yang sangat mencolok dibandingkan dengan berbagai otonomi yang lain. Ketiganya semakin mengukuhkan keberadaan dan status syariat Islam di Aceh.

Selain otonomi yang diberikan oleh Undang-Undang No. 18 tahun 2001 tersebut, dalam masalah syariat Islam, NAD telah mendapatkan perluasan kewenangan yang cukup signifikan. Pada tanggal 4 Maret 2003, bertepatan dengan tanggal 1 Muharram 1424 
$\mathrm{H}$, dengan terbitnya Keputusan Presiden (Keppres) Nomor 11 Tahun 2003 sebagai dasar dari pembentukan Mahkamah Syariah, NAD secara resmi memiliki Mahkamah Syariah, salah satu unsur terpenting bagi penegakan syariat Islam. ${ }^{2}$

Keppres ini dinilai sebagai unsur terpenting sebab, Mahkamah Syariah ini yang merupakan perluasan dari peradilan agama, dapat menangani tiga bidang persoalan, ialah al-akhwal al-syakhsyiah (hukum keluarga), muamalat (perdata), dan jinayat (pidana). Meski demikian, masih ada kendala peraturan yang menjadikan tidak semua masalah dalam tiga bidang tersebut di bawa ke Mahkamah Syariah, yakni karena masih minimnya Perda (Qonun) yang sudah tersedia. Sedangkan untuk bisa ditangani dalam Mahkamah Syariah, haruslah didasari dengan penetapan Qonun dalam masalah yang bersangkutan.

Masuknya masalah jinayat ke dalam jurisdiksi Mahkamah Syariah tersebut, jelas merupakan perkembangan yang sangat menarik. Mengapa demikian? Hal ini dapat dilihat bahwa minus jinayat, sebenarnya pemberlakuan syariat Islam nyaris tidak ada kekhasannya. Sebab, jika hanya masalah hukum keluarga, tidak usah Indonesia yang mayoritas penduduknya muslim serta memelihara tradisi ke-Islaman yang cukup lama, namun negara-negara di mana penduduk muslim adalah minoritas, seperti Philipina, Thailand, atau bahkan Miyanmar, ${ }^{3}$ hukum keluarga pun tetap dijamin - meski dalam tataran realitas implementasi aturan tersebut tidak semulus di Indonesia. Karenanya, otonomi khusus tersebut kian memiliki makna dengan, diberikannya kewenangan lokal untuk penerapan jinayat.

Namun, suatu hal yang patut dicermati dalam kaitannya dengan jaminan otonomi khusus tersebut adalah, bagaimana latar belakang sosio-historis-kultural dari NAD sehingga dengan ini nanti bisa mendukung pelaksanaan syariat Islam. Sejauh mana secara historis bisa dirunut, pengalaman masyarakat Aceh dalam pemberlakuan syariat Islam, sejauh mana nilai-nilai ke Islaman menjadi sebuah budaya dan menyatu dalam diri masyarakat Aceh, tentu menarik untuk dilihat pembahasan berikut.

\section{Argumen Historis-Regional}

Masa lalu Aceh adalah sebuah, dalam tingkat tertentu, serpihan dari realita Islamic glory (futuhat al-(slamiyah). Aceh, pasca takluknya Malaka di bawah Portugis, bersama-sama dengan Kerajaan Islam Brunei, menggantikannya dalam hubungan dagang dengan Majapahit, di mana ketika itu Kerajaan Demak belum terwujud. Dalam penelitian yang dilakukan oleh Professor M. Bary Hooker yang kemudian dimuat dalam karya monumentalnya Islamic Law in Southeast Asia menyebutkan, di antara warisan kitab undangundang Islam pada masa lalu (pra kolonialisme) adalah; the Malacca Laws

${ }^{2}$ Republika 6 Maret2003 sebagaimana diposting dalam http://ilas.leidenuniv.n//host/inis/INL/docs/Kamis 06.03.doc)

${ }^{3}$ Tebba, Sudirman, ed., Perkembangan Mutakhir Hukum Islam di Asia Tenggara, (Bandung: Mizan, 1993). Hampir secara keseluruhan, buku ini berbicara tentang kondisi perkembangn hukum Islam di wilayah Asia Tenggara. Termasuk di dalamnya dibahas tentang aspek keberlakuan hukum Islam di masing-masing negara. 
(hukum Malaka), Aceh Laws,(hukum Aceh), Miangkabau Laws (hukum Minangkabau), the Luwaran of Manguindanao and the Sulu Codes (hukum Luwaran bagi wilayah: Mindanau dan Sulu), serta beberapa aturan hukum Islam Jawa: dan Serawak: ${ }^{4}$. Hukum Aceh itu sendiri, terbagi-bagi dalam beberapa . teks; ada kumpulan aturan yang disebut Adat . (Bandar). Aceh, Majelis Aceh dan Mahkota Alam. Ketiganya memiliki bidang pengaturanyang saling berbeda: Hal ini jelas menunjukkan: betapa masa lalu Aceh adalah sebuah. masyarakat dengan nuansa ke. Islaman yang : kental dan tinggi.:- Bahkan, karena telah. kentalnyanuansa syariat di dalam tradisi Aceh; terrefleksikan salah - satu - semboyan -yang dipegang masyarakat Aceh: "Adat bak Po Teumeureuhom; hukom bak Syiah Kuala; Qanun bak Putro Phang; Reusam bak Laksamana" (adat dari Sultan', hukum dari Ulama, Qanun dari Putri Pahang, reusam dari

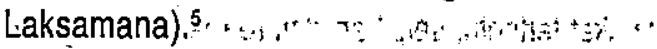

1.Di samping dokumen berbagai: kitab hukum tersebut; dokumen yang ditulis oleh $\mathrm{Ibnu}$. Batutah-pun; , seorang pengembara muslim. abad ke empatbelas, rmemberikan gambaran yang:makin menguatkan kesimpulan di atas: Ibnu Batutah telah mencatat fakta historis. tentang betapa kental suasana ke Islaman Aceh. dalam.' karya' monumentalnya' 'Tuhfat al-Nazzar fi Ghara'b al-Amshar wa 'Aja'ib al-Asfar' atau yang , populer dengan nama 'Rihlah Ibnu Bathuthah'. Disebutkannya tentang kunjungannya di sebuah. kerajaan dipesisir Sumatera, yang "menerapkan hukum figh mazhab Syafi i, rakyatnya senang berjihad dan perang tetapi mempunyai sifat tawadhu' yang tinggi." Fakta-fakta ini mengisyaratkan bahwa Aceh merupakan kekuasaan politik Islam-yang secara signifikan telah ikut memainkan peran dalam Islamisasi nusantara, dan lebị dari, merupakan kekuatan yang sangat diperhitungkan dalam skala regional.

: Aspek lain yang barangkali bisa menambah kelengkapan deskripsi tentang kondisi sosio-kultural masyarakat Aceh adalah adanya struktur masyarakat Aceh masa lalu, di mana seluruh: wilayah kerajaan Aceh akhir abad ke: 13 ; terbagi lebih dari seratus nanggro (negeri), yang setiap negeri dipimpin hulubalangy yang-dibantu seorang ulama besar bertindak , sebagai - qadi, yang dalam penyelesaian-perkara yang dihadapinya dibantu, dua ahli agama? Lebih: dari itu, kuatnya semangat-ke Islaman di Aceh bisa dilihat dari parameter kuatnya. semangat membela agama; -atau yang lebih populer dengan istilah perang sabil. Perang melawan Belanda yang kafit $\mathrm{y}_{\mathrm{j}}$ tidak bisa dipisahkan dari perang agama ini. Semangat orang Aceh terekam dalam pernyataan K. Van Der Maaten (1896) sebagai berikut:

"Satu-satunya peperangan rakyat yang pernah dialami oleh Belanda di seluruh

$\therefore$ Nusantara ; hanyalah perang Aceh. Pada $\therefore$ masa itu benar-benar dapat disebut, bahwa, setiap laki-laki, setiap perempuan - dan setiap anak-anak menjadi musuh kita, bukan karena mereka itu menaruh hormat atau mengagumi pemimpin mereka,

${ }^{4}$ Hooker, M. Barry, Islamic Läwin Southeast Asia, (Singapore: Oxford University Press, 1984), hlm 9-30

5.Penjelasan Atas Undang-Undang Republik Indonesia Nomor 18 Tahun 2001 Tentang Otonomi Khusus Bagi Provins jaerah Istimewa Aceh Sebagai Provinsi Nanggroe Aceh Darussalam. Point I. Umúm.

${ }^{6}$ 'Rasyid, Daud, 'Mencari Formulasi Syariah di Serambi Mekah' (Republika, 13/11/99)

'Shiddiqi, Nourouzzaman, Jeram-Jeram Peradaban Muslim, (Yogyakarta: Pustaka Pelajar, 1996), hlm.315. 
melainkan karena keyakinan mereka yang mendalam dan benci kepada kafir". ${ }^{8}$

Realita itu menunjukkan bahwa, Aceh memiliki landasan historis yang kuat bagi diberlakukannya syariat Islam. Karenanya pemberlakuan syariat Islam itu sendiri bukanlah sesuatu yang a-historis, tidak linier. Artinya, bahwa hal tersebut merupakan hal yang bukan saja layak (feasible), namun bahkan merupakan keharusan sejarah apabila masyarakat Aceh tidak ingin mereka tercerabut dari akar historis.

Bukankah sudah menjadi hal yang dipahami secara umum, bahwa salah satu argumen kuat yang diajukan dalam mendukung upaya sparasi beberapa pihak pro-independensi adalah bahwa secara politik masyarakat Aceh telah dibohongi, yakni bahwa mendiang Presiden Soekamo, yang pernah menangis di pangkuan Tengku Daud Beureueh telah berjanji untuk memberikan kebebasan pemberlakuan syariat Islam di Aceh, meski ternyata janji tersebut hanyalah kebohongan. Itulah di antara alasan politis yang telah mendorong lahirnya 'pembangkangan' Aceh terhadap pemerintah pusat.9

Atas dasar itulah dapat dikatakan bahwa secara sosologis dan kultural, Aceh memang merupakan wilayah yang relatif kondusif untuk pemberlakuan syariat Islam. Artinya, apabila masyarakat Aceh diberikan sebuah otonomi khusus yang berkaitan dengan kebebasan melaksanakan syariat Islam, hal itu ibarat 'ayam yang pulang ke induknya', merupakan sesuatu yang telah lama hilang namun akhirnya ditemukan kembali. Dan ini, menjadi modal kultural dan sosiologis yang sangat berharga, yang sulit bagi daeran lain untuk memilikinya.

\section{Basis Institusional dan Kultural Bagi Implementasi Syariat Islam}

Apa kaitan antara sub tema ini dengan tema besar tulisan ini, ialah di seputar reinvigorasi syariat Islam di NAD? Barangkali itulah suatu hal yang harus dikemukakan untuk memulai pembahasan basis institusional dan kultural yang diperlukan bagi penegakan syariat islam.

Syariat Islam, yang dalam definisi bakunya adalah keseluruhan ajaran Islam, baik yang terkait dengan aspek aqidah, ibadah, muamalah, akhlaq dan aspek-aspek lainnya dari ajaran Islam, telah menjadi istilah yang umum yang maksudnya adalah keseluruhan aspek hukum Islam. ${ }^{10}$ Dalam konteks politik, syariat Islam berarti pemberlakuan ajaran Islam dalam kehidupan bernegara, praktis hal itu juga akan mencakup, hukum Islam yang telah mengalami positifisasi, atau yang dengan istilah lainnya adalahi telah mengalami proses peng-Qanun-an.

Sebagai sebuahi hukum tentu saja keberlakuan syariat Islam memerlukan berbagai prasyarat utama. Tanpa terpenuhinya prasyarat tersebut, tentu apa yang, disebut dengan pemberlakuan syariat: Islam, pada

${ }^{8}$ Shiddiqi, ibid. hlm. 317.

${ }^{9}$ Apa yang disebut pembangkangan ini dimaksudkan sebagai ungkapan lain dari pemberontakan yang terjadi pada masa Daud Beureuh, serta kemudian dilanjutkan dengan adanya Gerakan Aceh Merdeka (GAM), dalam 'Hubungan Sipil-Militer diAceh, Kebencian Itu Sudah Bertindih Lapis' dalam http://www.indomedia.com/ serambi/2000/1411h11.htm tgl 14. jam 16.19. 
hakikatnya hanya formalitas, dan tidak mustahil, hanya penyebutan untuk sesuatu yang sebenarnya sudah berlaku selama ini, ialah penerapan 'hukum Islam dalam masalah hukum keluarga. Jika hanya hal ini yang akan tetap berlaku, itupun dengan opsi hukum yang banyak memberikan kesempatan orang muslim untuk memilih apakah dengan hukum Islam catau hukum sipil untuk menyelesaikan perkaranya, tentu penyebutan pemberlakuan syariat Islam hanyalah wacana yang sepi dalam kenyataannya. 'Karena itulah, dalam konteks ini menarik untuk didiskusikan selanjutnya tentang berbagai aspek yang terkait dengan penegakan syariat Islam di Aceh.

Menurut Lawrence M. Fredman," bahwa hukum dan penegakannya, pada hakikatnya terdii dari tiga unsur, structure (aparat penegak hukum), culture (budaya hukum), serta substance (substansi hukum itu sendiri). Berdasar teori ini maka, hanya dengan adanya tiga unsur tersebut akan berjalan sebuah hukum dalam masyarakat. Kelemahan dalam salah satu atau ketiga aspek tersebut akan berakibat pada terganggunya penegakan hukum dalam masyarakat. Untuk itu, sangat penting kiranya dalam kesempatan ini untuk melihat upaya penegakan syariat Islam di Aceh pasca tsunami dengan menganalisis berbagai peluang dan kemungkinan dari ketiga aspek tersebut.
Pembangunan kembali Aceh merupakan sebuah momentum potensi peneguhan kembali pemberlakuan syariat Islam. Karena jika melihat berbagai upaya reformasi hukum, di antara pendapat yang berkembang menyatakan bahwa pemberlakuan sebuah hukum baru memerlukan langkah-langkah dan upaya yang tidak ringan. Meskipun dalam latar belakang historis-sosiologis dan kultural didapat kesimpulan bahwa Aceh memang sangat dekat dengan syariat Islam, namun semua itu bukanlah jaminan bahwa setelah sekian lama vacum dari syariat Islam dikarenakan secara politik tidak pernah diberi kesempatan untuk itu - masyarakat tidak 'terkontaminasi' dengan berbagai pandangan yang berbeda dari pandangan masyarakat Aceh masa lalu. ${ }^{12} \mathrm{Di}$ sinilah mengapa ketiga aspek penegakan hukum tersebut perlu dibangun.

\section{Pembaruan Aparat Hukum}

Di antara kritik yang terlontar dalam kaitannya dengan otonomi khusus (penegakan syariah) di NAD adalah bahwa pelaksanaannnya dipenuhi dengan "kemunafikan". ${ }^{13}$ Maksud dari pemyataan tersebut adalah bahwa para aparat penegak pemerintahan di Aceh ternyata sangat jauh dari pencerminan spirit untuk penegakan syariat Islam. Dengan kata lain,

${ }^{10}$ Penjelasan tentang klarifikasi istilah ini bisa dibaca pada buku yang berjudul Zaidan, Abdul Karim, alMadkhal li Dirasah al-Syari'ah al-Islamiyah, Bagdad: Matba'ah al-'Ani, 1969, hlm. 13. Lihat juga Khallaf, Abdul Wahhab, Im Ushul al-Figh, (Kuwait: Dar al-Qalam, 1979), hlm. 11

"Friedman, Lawrance M, 'Legal Culture and Social Development, dalam Friedman, Lawrance $M$ dan Macaulay, Stewart, Law and The Behavioral Sciences, (New York: The Bross-Merrill Company Inc). hlm 1000-1005.

${ }^{12}$ Bentuk dari 'kontaminasi' ini adalah, yang paling utama, proses sekularisasi yang memberikan imbas pada pandangan manusia tentang agama dengan segenap perangkat aturan yang dimilikinya. Proses sekularisasi, seperti yang dijelaskan oleh Turner, Bryan S, Religion and Social Theory (London: Sage Publications, 1997) menyebutkan bahwa industrialisasi bisa menyebabkan menipis/hilangnya kontrol agama terhadap berbagai aktivitas manusia. 
bahwa penegakan syariat islam hanyalah lipservice, slogan dan jargon politik yang kering akan etos dan spirit. Memang tidak bisa diambil kesimpulan bahwa masyarakat Aceh juga mengalami hal yang sama, namun setidaknya hal itu bisa memberikan potret sosiologis dan kultural bahwa tidak seluruh lapisan masyarakat memiliki semangat akan hal itu. Padahal, penegakan hukum memerlukan aparat yang memiliki komitmen dan loyalitas bagi cita-cita hukum. Karena itulah pertanyaan selanjutnya adalah bagaimana cita-cita syariat Islam itu kelak bisa terwujud.

Dalam kaitannya dengan perlunya aparat yang baik dalam penegakan hukum, maka dalam kasus Aceh, pembangunan kembali Aceh memberikan peluang yang cukup lebar bagi upaya pewujudan aparat yang lebih baik. Sebagaimana telah banyak diketahui bahwa dalam pembaruan mentalitas aparat agar kondusif terhadap penegakan hukum, banyak pengalaman yang telah dilalui oleh berbagai negara. Selain melakukan pendidikan dan training-training, juga ada cara yang lebih radikal, ialah dengan cara 'amputasi'. ${ }^{14}$ Yang dimaksudkan dengan metode amputasi adalah bahwa aparat yang rusak haruslah dipensiunkan untuk kemudian diganti dengan aparat baru yang lebih segar dan, relatif tidak memiliki mata rantai yang menyambungkannya. dengan aparat sebelumnya. Dengan aparat yang baru, maka mereka akan mudah mengikuti budaya hukum baru.

Maka, pembangunan kembali Aceh merupakan momentum yang baik bagi lahirnya sebuah mentalitas aparat yang baru, memungkinkan adanya setting-up yang lebih terprogram dan terintegrasi secara proporsional. Tidak terlalu sulit, dalam konteks seperti ini, bagi Aceh untuk mendapatkan aparat-aparat yang ralatif mampu dan memungkinkan untuk disesuaikan dengan kebutuhan penegakan syariat Isiam. Inilah di antara aspek yang sangat penting untuk diperhatikan dalam konteks pembangunan kembali Aceh. Mengingat, bahwa penegakan syariat Islam sangat berbeda karakter dengan penegakan hukum positif yang lepas dari sakralitas dan berbasis pada prinsip-prinsip ketuhanan dan keagamaan. Dengan aparat 'konvensional' yang memiliki mindset 'konvensional' juga, agaknya sangat sulit idealitas dari cita dan citarasa penegakan syariat Islam bisa terwujud. ${ }^{15}$ Dan itulah urgensi

${ }^{13}$ Penilaian bahwa penerapan syariat Islam di Aceh terkesan main-main, dilontarkan oleh sebagian tokoh Islam pada kegiatan silaturahmi dan tabligh akbar diikuti sekitar 2.000 umat muslim, baik mayarakat NAD maupun para relawan. Hadir dalam acara itu Alyasa Abu Bakar (Ketua Dinas Syari'ah NAD), Muslim Ibrahim (Ketua Majelis Permusyawaratan Umat NAD), Habib Rizieq Shihab (Ketua FPI), Irfan SAwwas (Ketua Lajnah Tanfidziyah MMI), serta sejumlah tokoh NAD. Acara ini disiarkan secara langsung oleh Radio Suara Baiturrahman. (Republika, 25 Februari 2005).

${ }^{14}$ Istilah 'amputasi' politik ini biasa dipakai untuk menyebutkan perombakan aparat pemerintahan yang memang sudah tidak layak dipertahankan, mislanya, dalam tulisan Agus Haryadi yang berjudul 'Revolusi (Tak) Berhenti di Hari Minggu' (Sinar Harapan, 3 April 2002)

${ }^{15}$ Dennny Kodrat, dalam artikelnya yang berjudul 'Quo Vadis Mahkamah Syariah' (Pikiran Rakyat, 08 Maret 2003) juga mengungkap adanya kendala kesiapan sumber daya penegak syariat. Menurutnya, dibutuhkan penegak syariat, baik itu dari polisi (syurthah) dan hakim (qadhi) yang tidak hanya ikhlas, tapi juga mumpuni dalam tsaqafah Islam. 
dari pembaruan aparat penegak hukum. Dan Aceh, hari ini memiliki kesempatan yang baik untuk mem-blueprint-kan aparatnya.

\section{Problem Substansi Hukum}

Yang dimaksudkan dengan substansi hukum di sini adalah isi dari keseluruhan hukum syariat Islam itu sendiri, terkait dengan, baik hukum materiil maupun hukum formilnya. Di sini, pekerjaan legislasi sangat teruji, bukan saja untuk berbicara masalah frekuensi produk hukum yang dihasilkannya, namun juga terkait dengan kualitas produk hukum yang dihasilkan. Produk hukum yang dimaksud adalah apa yang oleh UU Otonomi Khusus NAD dengan istilah Qanun.

Memang bukan suatu hal yang ringan untuk melakukan proses legislasi (Qonunisasi) hukum Islam, baik dari prinsip-prinsip dalam ground norm-nya (dalam hal ini al-Qur'an dan sunnah) maupun melakukannya dari bahan baku fiqih (pendapat para yuris). Terlebih yang berkaitan dengan hukum formil, tentu memerlukan kemampuan dan keahlian yang tinggi. Problem yang sangat berat dihadapi memang dalam hal bagaimana bahasa fiqih harus dirubah ke bahasa hukum, sedangkan selama ini masyarakat Indonseia umumnya sangat terbiasa, atau bahkan sementara merasa cukup, dengan model fiqih. Seriusnya problem ini sebenarnya sudah tergambar dengan minimnya produk perundangundangan yang telah dihasilkan di NAD pasca otonomi khusus ini.

Sebuah penegakan hukum, dalam hal ini sangat terkait dengan substansi hukum tersebut. Karena itulah, harus diciptakan Qonun yang memenuhi beberapa kriteria yang berkaitan, baik aspek kesederhanaannya maupun muatan hukum di dalamnya. Artinya, bahwa isi dari syariat Islam, ketika dimasukkan dalam sebuah produk legislasi (Qonunisasi), haruslah disajikan dengan bahasa yang mudah untuk dipahami oleh berbagai lapisan masyarakat. Meski demikian, muatan materi juga menjadi aspek yang tidak boleh diabaikan. Karena itulah, proses legislasi ini bukanlah suatu pekerjaan yang bisa dipandang ringan. Apabila ingin dilihat untuk kemudian dikomparasikan, di dunia internasional, sebenarnya banyak produk perundang-undangan yang merupakàn proses Qonunisasi dari syariat Islam. Namun, tentu saja masyarakat Aceh memiliki ciri khas dan indentitas yang berbeda dengan berbagai negara Islam dalam lingkup internasional. Aceh, dalam pemahaman fiqih (hukum Islam aplikatif) memiliki madzhab yang berbeda dengan berbagai negara Islam yang lain. Ciri khas Islam Asia Tenggara -antara lain madzhab Syafij-berbeda dengan muslim di wilayah lain, wilayah Balkan misalnya yang lebih condong ke Madzhab Hanafi, Asia Barat yang lebih condong ke madzhab Hambali maupun Hanafi, atau muslim di Anak Benua (India, Pakistan, Bangladesh) yang lebih condong ke madzhab Hanafi, dan seterusnya. Tentu saja, Qonun yang dilahirkan pun, tidak dapat melepaskan atau tercerabut sama sekali dari akar muasal hukum Islam di masa lalu Aceh, pada masa kejayaan berbagai kerajaan Islam masa lalu, meskipun hal ini juga tidak berarti bahwa Qonun yang dilahirkan nantinya tidak mengantisipasi dan mengakomodasi perkembangan zaman.

\section{Pembangunan Budaya Hukum}

Dalam kenyataannya, budaya hukum 
telah memberikan peran yang sangat penting bagi gagal atau suksesnya sebuah penegakan hukum dalam berbagai masyarakat (bangsa). Meskipun sebuah aturan atau perundangundangan itu telah memenuhi syarat dalam proses legal drafting, dalam substansinya juga mengandung nilai-nilai yang sangat idẹal dan akomodatif terhadap berbagai persoalan, namun tetap ada sebuah aspek krusial yang tidak bisa diabaikan, jalah budaya hukum atau yang dikenal dengan istilah legal culture. Sebuah contoh yang sangat mudah disebut adalah kasus pelanggaran hak cipta (intellectaul property rights). Meskipun berbagai perangkat pengaturannya telah ada, namun dikarenakan budaya hukum masyarakat yang ada masih menganggap bahwa pelanggaran hak cipta adalah hal yang biasa, maka, pengaturan ini sulit ditegakkan. Penegakannya pun hanya dalam kasus-kasus yang benar-benar penting dan strategis. Sehingga, apa yang tertulis dalam undangundang tidak terwujud sebagai suatu bentuk hukum yang ideal, ialah hukum yang hidup dalam masyarakat. ${ }^{16}$

Karena itulah, budaya hukum sering berperan melebihi dari peran kedua aspek hukum di atas (aparat dan substansi hukum tertulis). Jika pada dua aspek di atas bisa dilakukan pembentukan (pengadaan) dalam waktu yang relatif singkat, maka, budaya hukum ini memiliki karakter yang sangat berbeda. Dia memerlukan suatu proses internalisasi yang tidak sporadis dan insidental. Sebagai contoh bahwa pembentukan budaya hukum memerlukan waktu yang lama adalah fakta yang terjadi di Indonesia pasca reformasi ini. Meski berbagai produk perundang- undangan baru banyak dilahirkan, misalnya yang berkaitan dengan Pemilihan Umum (Pemilu), Pemilihan kepala Daerah (Pilkada), Anti Korupsi, Otonomi Daerah (Otda), dan banyak lagi yang lainnya, serta, dibentuk pula berbagai komisi kenegaraan yang membidangi berbagai aspek, seperti, Komisi Pemilihan Umum, Komisi Penyiaran, Komisi Hak Asasi Manusia, Komiși Pemberantasan Korupsi, namun, tetap saja, keberadaan berbagai perangkat baru tersebut bukan saja belum dapat berfungsi secara normal sebagaimana platform-nya, tetapi justr" menjadi semacam peluang baru untuk melakukan berbagai upaya yang merugikar, negara dan menguntungkan pribadi dan kelompok, antara lain, sebagai ladang korups: baru. Untuk itu, masalah pembentukan buday hukum ini memerlukan upaya yang serius integratif dan berkesinambungan.

Dalam konteks pembangunan kembali NAD pasca bencana, hal ini sangat tepat unte' memulai sebuah budaya hukum yang bart Dengan penataan ulang, sebenarnya rekayas. pembentukan kultur baru lebih memungkink2.। Misalnya saja dengan memberika! serangkaian Qonun dan kode etik ba.s pegawai dan juga masyarakat. Sehubungat' dengan upaya penegakan syariat Islam mak budaya hukum Islam (syariat Islam) sud jelas berpeluang besar untuk menjao. pengganti berbagai kultur yang telah ac' sebelumnya. Tidak bisa dipungkiri, bahwa antara kendala yang selama ini dihadapi ofe upaya penegakan syariat Islam di NAD adals masalah budaya hukum, dan buda: masyarakat pada umumnya. Dimungkink: program 'perusakan' kultur dan sistem $r_{1}$

${ }^{16}$ Soekanto, Soerjono. Pokok-pokok Sosiologi Hukum, (Jakarta: Raja Grafindo Persada, 2001), hlm 
dalam tradisi masyarakat secara sistematis yang dilakukan oleh kaum oportunis dengan 'ganjaisasi' masyarakat NAD, jika tidak dihentikan dengan agenda pembangunan kultur yang baru, akan menjadi agen perusakan moral dan nilai kultural, dan pada akhirnya, akan menjadi sangat kontras dengan agenda penegakan syariat Islam.

Mengapa mesti ada sebuah reorientasi kultural dari budaya hukum lama menuju yang baru, tentu saja karena karakter khas syariat Islam. Sebagaimana yang telah dikenal dalam antropologi sosial, bahwa budaya, sebenarnya dilahirkan atau diturunkan (diderivasikan) dari sebuah nilai-nilai yang divine, yang dari hal itu - akan melahirkan sebuah cultural values nilainilai kultural, yang pada gilirannya akan membentuk sebuah budaya. ${ }^{17}$ Karena itulah, paling tidak di sini ada ke-khas-an (eksklusivitas) yang harus dipertahankan. Sehingga, pada akhirnya 'deklarasi' penegakan syariat Islam akan menjadi sebuah realita yang memiliki akar dan mendapatkan urgensinya dalam kalangan masyarakat Aceh.

\section{Simpulan}

Berdasar pembahasan tersebut, dapat diambil kesimpulan bahwa penerapan syariat Islam di NAD, adalah sesuatu yang linier dengan basis kultural masyarakat Aceh. Pembangunan kembali Aceh pasca tsunami adalah sebuah momentum baru yang memiliki banyak titik signifikansi bagi agenda penerapan syariat Islam. Karena syariat Islam sebagai sebuah sistem hukum, maka tiga aspek yang berkaitan dengan upaya penegakan hukum pun harus diperhatikan yaitu: aparat, substansi dan budaya hukum. Minimal, tiga hal tersebut menjadi sesuatu yang sangat urgen untuk dipertimbangkan dalam pembangunan kembali Aceh, meski blue-print sudah terwujud, namun berbagai elemen penting ini dapat menjadi konsideran yang sangat berharga bagi upaya implementasinya, bisa mengisi jeda-jeda kosong di sela-sela pembangunan kembali masyarakat NAD.

\section{Daftar Pustaka}

Dennny Kodrat, 'Quo Vadis Mahkamah Syariah' dalam Pikiran Rakyat, 08 Maret 2003

Friedman, Lawrance $M$, 'Legal Culture and Social Development', dalam Friedman, Lawrance M dan Macaulay, Stewart, Law and The Behavioral Sciences, New York: The Bross-Merrill Company Inc.

Haryadi, Agus yang berjudul 'Revolusi (Tak) Berhenti di Hari Minggu', Sinar Harapan, 3 April 2002

Hooker, M. Barry. 1984. Islamic Law in Southeast Asia, Singapore, Oxford University Press,

Khallaf, Abdul Wahhab. 1979. IIm Ushul alFigh, Kuwait, Dar al-Qalam

Koentjaraningrat. 1981. Kebudayaan, Mentalitas dan Pembangunan, Jakarta, PT Gramedia

Rasyid, Daud, Mencari Formulasi Syariah di Serambi mekah, Republika, 13 November 1999

Shiddiqi, Nourouzzaman. 1996. Jeram-Jeram Peradaban Muslim, Yogyakarta, Pustaka Pelajar

${ }^{17}$ Koentjaraningrat, Kebudayaan, Mentalitas dan Pembangunan, (Jakarta : PT Gramedia, 1981), hlm 10-20 
Soekanto, Soerjono.2001. Pokok-Pokok Sosiologi Hukum, Jakita, Raja.Grafindo Persada

Tebba, Sudirman, ed. 1993. Perkembangan Mutakhir Hukum Islam di Asia Tenggara, Bandung: Mizan.

Turner, Bryan S. 1997. Religion and Social Theory, London, Sage Publications

Zaidan, Abdul Karim. 1969. al-Madkhal li Dirasah al-Syari'ah al-Islamiyah, Bagdad, Matba'ah al-'Ani

Undang-Undang Republik Indonesia Nomor 18 Tahun 2001 Tentang Otonomi Khusus Bagi Provinsi Daerah Istimewa Aceh Sebagai Provinsi Nanggroe Aceh
Darussalam.

Penjelasan Atas Undang-Undang Republik. Indonesia Nomor 18 Tahun 2001 Tentang Otonomi Khusus Bagi Provinsi Daerah Istimewa Aceh Sebagai Provinsi Nanggroe Aceh Darussalam.

Republika 6 Maret 2003

Republika, 25 Februari 2005

http://iias.leidenuniv.ni/host/ inis/INL/docs/ tgl 25 Mei 2005 jam 13.30

Tp, 'Hubungan Sipil-Militer di Aceh, Kebencian Itu Sudah Bertindih Lapis' dalam http://www.indomedia.com/ serambi/2000/1411h11.htm tgl 14. Mei 2005 jam 16.19. 